\title{
PSIGIATRIESE PASIëNTE SE BELEWENIS VAN HUL BEHANDELING DEUR DIE INTERPROFESSIONELE GESONDHEIDSPAN IN 'N PRIVAAT PSIGIATRIESE KLINIEK
}

\author{
H.E. Stols, M. Greeff en M. Poggenpoel
}

\section{INLEIDING}

Hedendaagse psigiatriese dienslewering word deur ' $n$ verskeidenheid multi-professionele spanlede gelewer. As gevolg van die kompleksiteit van die oorsake en aard van geestesongesteldheid en die moderne tendens om te spesialiseer, het elke professionele groep 'n afsonderlike en unieke inset om te lewer. Daar bestaan egter ook talle "grys" areas van oorvleueling. Hierdie "grys" areas ontstaan as gevolg van verskillende faktore, maar veral as gevolg van die professionele groepe se gemeenskaplike ondersteunende en terapeutiese funksies, asook die gebruikmaking van persoonlikheidsteoriee wat as gemeenskaplike verwysingsraamwerk deur almal benut word (SARV, 1985: 5; Wilson \& Kniesl, 1983: 55).

Op nasionale vlak bestaan daar tussen verskillende professionele groepe met hul onderskeie professionele verenigings en rade, 'n onderlinge wedywering om bepaalde aspekte van behandeling met behulp van wetlike verskansing eksklusief vir hulself afgebaken te kry. Hulle poog dus om ander professionele groepe wat wel oor voldoende agtergrondkennis, opleiding en praktiese vaardigheid beskik van dienslewering uit te sluit (SARV, 1988: 5; McDonald \& Rizer, 1988: 260).

Te midde van die konflikte word daar dikwels vergeet dat die interprofessionele gesondheidspan daar is ter wille van die pasient en nie andersom nie (Seidel, 1986: 64).

\section{DOELSTELLINGS}

Die doelstellings van hierdie studie was die volgende:

1. Om 'n verkenning te doen van psigiatriese pasiënte se belewenis van hul behandeling deur ' $n$ interprofessionele gesondheidspan in 'n privaat psigiatriese kliniek.

2. Om riglyne daar te stel vir die optimale benutting van die interprofessionele gesondheidspan se bydrae in die behandeling van psigiatriese pasiënte in 'n privaat psigiatriese kliniek, met spesifieke verwysing na die bydrae van die psigiatriese verpleegkundige en met die oog daarop om geestesongesteldheid by psigiatriese pasiënte te voorkom.

\section{NAVORSINGSONTWERP EN -METODE}

Die navorsingsontwerp en -metode wat in hierdie studie gevolg is, word kortliks uiteengesit.

\section{Navorsingsontwerp}

Hierdie studie was kwalitatief en verkennend van aard, met die doel om begrip en kennis aangaande individuele psigiatriese pasiènte se belewenis van hul behandeling deur die interprofessionele gesondheidspan te vermeerder. Dit was kontekstueel van aard omdat pasiënte uit 'n spesifieke privaat psigiatriese klinick by die studie betrek was (Burns \& Grove, 1987: 39; Mouton \& Marais, 1988: 43).

\section{Navorsingsmetode}

By die navorsingsmetode wat gevolg is, was veral die volgende aspekte belangrik: betroubaarheid en geldigheid; steekproefneming; data-insameling; dataverwerking; resultate en aanbevelings.

\section{- Betroubaarheid en geldigheid}

Om die gevaar van nie-betroubare resultate teen te werk, is kontrolemaatreèls met betrekking tot die posisie of status van die navorser, keuse van deelnemers, sosiale konteks en metode en prosedure van die studie toegepas (Stols, 1992: 16-19).

Die gevaar van nie-geldigheid is teĕgewerk met behulp van kontrolemaatreèls ten opsigte van die geskiedenis en ryping van data, waarnemereffekte, keuse van deelnemers en dataregressie, asook mortaliteit van data (Stols, 1992: 19-22; Woods \& Catanzaro, 1988:136-137).

\section{- Steekproefneming}

'n Nie-waarskynlike steekproef wat spesifiek doelgerig en gerieflik was en wat vrywillige deelname van deelnemers vereis het, was geneem. Die steekproef is geneem uit die steekproefpopulasie wat al die pasiente van 'n spesifieke privaat psigiatriese kliniek in die Transvaal was, en deur ' $n$ interprofessionele gesondheidspan behandel is. Die deelnemers het bestaan uit die eerste vyftien pasiënte en wat tydens die drie spesifieke weke waartydens data-insameling gedoen is aan die kriteria vir insluiting by die studie voldoen het. Hulle was direk voor data-insameling aan psigiatriese behandeling deur ' $n$ interprofessionele gesondheidspan blootgestel (Abdellah \& Levine, 1979: 333-335; Cobb \& Hagemaster, 1987: 138; Wilson, 1985: 57, 68).

- Data-insameling

Met behulp van die fenomenologiese navorsingsmetode is die verskynsel van psigiatriese behandeling deur 'n interprofessionele gesondheidspan ontdek soos dit tydens deelname aan die situasie deur pasiënte beleef is. Die navorser het 'n bepaalde 
rol vervul en die strategiee van "intuïtering" en "tussen hakies plaas" is toegepas.

Voorbereiding vir data-insameling was gerig op die werwing van deelnemers en die verkryging van ingeligte toestemming. Om datainsameling te inisieer, is deelnemers versoek om 'n spontane skets in hul eie woorde te skryf oor:

"My envaring van my behandeling deur die personeel uit die verskillende beroepsgroepe".

Met behulp van kommunikasietegnieke is opvolgonderhoude met deelnemers in 'n bepaalde fisiese opset gevoer om die inhoud van die geskrewe sketse te verifieer en verder te verken. Die opvolgonderhoude is op band geneem en verbatim getranskribeer. Veldnotas is van onderhoude geskryf ter wille van konteksbepaling (Abdellah \& Levine, 1979: 339; Omery, 1983: 57; Parse, Coyne \& Smith, 1985: 5, 18; Wilson, 1985: 57, 68-70; Woods \& Cantanzaro, 1988: 136).

\section{- Dataverwerking}

Dataverwerking het plaasgevind deur gebruikmaking van die strategieè van "intuittering" en "tussen hakies plaas". Dataverwerking het op 'n tweeledige wyse geskied naamlik: 'n inhoudsanalise uit al die deelnemers se spontane sketse en transkripsies wat aan die hand van universele kategoriee gekwantifiseer is, en 'n kontekstuele beskrywing van al die deelnemers se belewenisse gesamentlik. Universele kategorieë wat geïdentifiseer is, is dié van interne fisieke omgewingsfaktore; eksterne fisiese omgewingsfaktore; interne psigologiese omgewingsfaktore; eksterne sosiale omgewingsfaktore; geestelike omgewingsfaktore; nie-klassifiseerbare faktore en 'n integrasie van voorafgaande faktore.

Betroubaarheid van die inhoudsanalise is deur kodering deur 'n navorser en 'n psigiatriese verpleegspesialis as medekodeerder verseker. 'n Werksprotokol vir kontrole van die inhoudsanalise is aan die medekodeerder voorsien. Die metode van dataverwerking het volgens 'n integrasie van die vyf basiese stappe van Giorgi se metode en Kerlinger se metode verloop wat ' $n$ universum, eenhede van analise en kwantifisering insluit (Burns \& Grove, 1987: 81; Kerlinger, 1986: 478-481; Omery, 1983: 57; Parse et al., 1985: 4, 19, 20, 21; Woods \& Cantanzaro, 1988: 136).

Resultate is gekwantifiseer op grond van die aantal deelnemers wat na dieselfde kategorie of tema verwys het. Dit is in tabelvorm angedui.

\section{- Literatuurkontrole}

Resultate is geverifieer deur 'n literatuurkontrole te doen. Daar is spesifiek op nuwe insigte en gevolgtrekkings wat uit dié studie voortgespruit het, gefokus (Woods \& Catanzaro, 1988: 136).
- Aanbeveling van riglyne, tekortkominge en toepassingswaarde

Inligting wat uit die studie en literatuurkontrole bekom is, is gebruik vir die opstel van riglyne om die bydrae van die interprofessionele gesondheidspan met die klem op die bydrae van die psigiatriese verpleegkundige in ' $n$ privaat psigiatriese kliniek optimaal te benut, ter voorkoming van die verergering van geestesongesteldheid. Sowel die tekortkominge as die toepassingswaarde van die studie is in ag geneem (Kerlinger, 1986: 481; Stols, 1992: 63-97).

\section{RESULTATE EN BESPREKING VAN RESULTATE}

\section{Inhoudsanalise}

Vir die bepaling van hooftemas vir bespreking is response van sewe of meer deelnemers wat na ooreenstemmende faktore verwys het, as beduidend geag. Die bestaansreg van sodanige temas of faktore is dus daarin geregverdig dat 'n beduidende aantal deelnemers hul belewenisse daarvan weergegee het. Die temas en subtemas is in prioriteitsvolgorde getabuleer. Betekenisvolle individuele voorbeelde is aangedui om te verseker dat die kwaliteit van belewenis behoue bly. Die hooftemas wat uitgekristalliseer het, het gekorrelleer met die verdeling van die universele kategorice en word vervol gens bespreek (Stols, 1992: 36-62).

\section{- Interne Fisieke Ongewingsfaktore}

Die besonderhede van deelnemers se fisiese belewenisse word in tabel 1 angedui.

Dit was opmerklik dat vyf uit vyftien deelnemers 'n aversie aangedui het om met hulle hande te werk, alhoewel sommiges tog later besef het dat deelname daaraan ' $n$ helende effek kan hê. Die navorser vermoed dat dit deur 'n kultuurgebonde houding beinnloed kon wees.

"Met my hande kan ekniks doen nie ... Sit my agter 'n lessenaar ... Ek is totaal onprakaies..."

\section{- Eksterne fislese omgewingsfaktore}

Uit tabel $\mathbf{2}$ is dit duidelik dat deelnemers die eksterne fisiese omgewing (milieu) hoofsaaklik in terme van die struktuur of daaglikse program en in terme van die atmosfeer wat deur die fisiese opset geskep is, beleef het.

Die pastorale beraders was onderskeidelik ook as voorligtingsielkundige en kliniese sosioloog gekwalifiseer. Die lesings wat deur hulle aangebied is, is deur sewe deelnemers beskryf as toepaslik, interessant, goed voorberei, leersaam en betekenisvol. Dit het egter die vraag laat ontstaan of die inhoud van die lesings as geestesgesondheidvoorligting geklassifiseer sou kon word of as ' $n$ onderdeel van Godsbelewenis. Op die oog af blyk dit eerder eersgenoemde te wees, in welke geval dit net

TABEL 1

\section{TEMA: BEHANDELINGSBELEWENIS VAN INTERNE FISIEKE OMGEWING}

\begin{tabular}{|c|c|}
\hline$N=11$ & $\begin{array}{l}\text { Verwye na fieleke aktlwiteite en sport } \\
\begin{array}{l}N=5 \quad-\text { Aversie in deelname aan handvaardighede } \\
N=2-\text { Kon dit finansieel nie bekostig nie }\end{array}\end{array}$ \\
\hline$N=9$ & $\begin{array}{l}\text { Verwye ne fisloke behandelingemetodes } \\
N=7 \text { - Positiewe belewenis van fisieke behandeling } \\
N=2 \text { - Verkies om sonder medikesie klaar te kom } \\
N=2 \text { - Positiewe belewenis van sleapterapie } \\
N=1 \text { - Huisdokter kan ook medikasie voorskryf }\end{array}$ \\
\hline$N=6$ & $\begin{array}{l}\text { Verwye na fieleke behoeftes } \\
N=4 \text { - Eles van hoogstaande gehalte } \\
N=2 \text { - Fisiek versterk na behandeling }\end{array}$ \\
\hline
\end{tabular}

TABEL 2

TEMA: BEHANDELINGSBELEWENIS VAN EKSTERNE FISIESE OMGEWING (MILIEU)

\begin{tabular}{|c|c|}
\hline$N=10$ & $\begin{array}{l}\text { Venwy na die strukluur van die program } \\
N=7 \text { - Lesings deur pastorale beraders positief } \\
N=3 \text { - Inhoud van opnamevorms dupliserend } \\
N=1 \text { - Arbeidsterapie georganiseerd } \\
N=1 \text { - Saalprogram ongeorganiseerd/ongedissiplineerd } \\
N=1 \text { - Slaaptyd oor naweke te vroeg }\end{array}$ \\
\hline$N=9$ & $\begin{array}{l}\text { Verwye na belewenis van fleiese milleu } \\
N=6 \text { - Positief: huislike atmosfeer } \\
N=5 \text { - Negatief } \\
N=2 \text { - Beperkte ruimte t.o.v. eetsaal, arbeidsterapie } \\
N=1 \text { - Tuin verwaartoos } \\
N=1 \text { - Tekort aan storte in 'n afdeling } \\
N=1 \text { - Tekort aan toesluitgarages }\end{array}$ \\
\hline
\end{tabular}


TABEL: 3

TEMA: BEHANDELINGSBELEWENIS VAN INTERNE PSIGOLOGIESE OMGEWING

\begin{tabular}{|c|c|}
\hline$N=15$ & Verwye na selfwaarde \\
\hline$N=15$ & $\begin{array}{l}\text { Verwye na kognitiowe aspekte } \\
N=10 \text { - Insig } \\
N=7 \text {. Persepsie van tyd }\end{array}$ \\
\hline$N=15$ & $\begin{array}{l}\text { Verwy na affektlew aspekte } \\
N=12 \cdot \text { Gevoel van welsyn } \\
N=9 \cdot \text { Ontsteld } \\
N=7 \cdot \text { Depressie } \\
N=7 \cdot \text { Liefde } \\
N=7 \cdot \text { Kalmte } \\
N=7 \cdot \text { Dankbaarheid } \\
N=5 \cdot \text { Aggressie }\end{array}$ \\
\hline$N=10$ & Verwye na konatiewe aspekte \\
\hline
\end{tabular}

TABEL 4

TEMA: BEHANDELINGSBELEWENIS VAN EKSTERNE SOSIALE OMGEWING

\begin{tabular}{|c|c|}
\hline$N=3$ & Veruye ne openbare meninge \\
\hline$N=7$ & Verwye na positiowe belewenis van medepaolënte \\
\hline$N=8$ & Verwye na negatlowe belewenie van medepasiēnte \\
\hline$N=8$ & Verwye ne bydrees van lede van die Interprofeesionele geeondhoidspan \\
\hline$N=15$ & 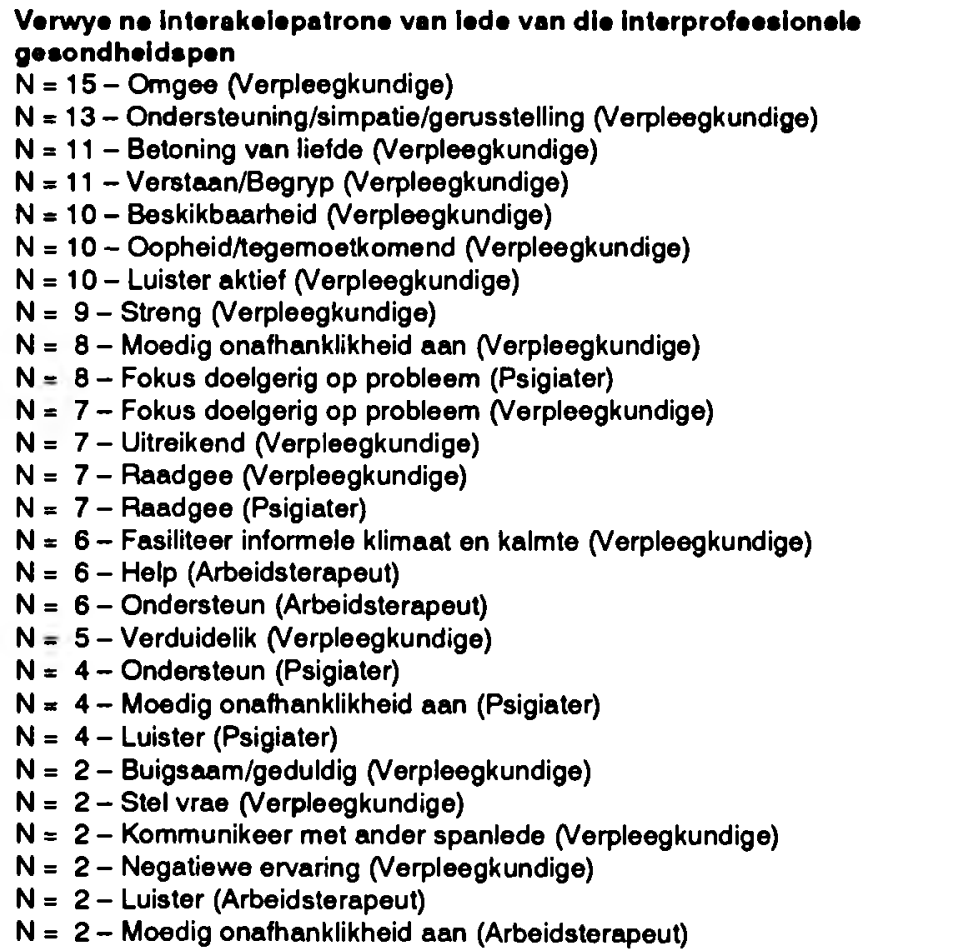 \\
\hline
\end{tabular}

sowel deur enige van die interprofessionele gesondheidspanlede aangebied sou kon word

Alhoewel dit op die oog af nie deel van behandeling deur die interprofessionele gesondheidspan was nie, het ses deelnemers verwys na die positiewe wyse waarop die kamers en tuine tot 'n huislike, informele, kalmerende atmosfeer bygedra het en ' $n$ invloed op hulle gemoedstoestand uitgeoefen het.
"Hmm, die tuin, en alles, as jy deur die venster kyk, alles lyk rustig waar hulle baie keer spuit en um ... mense wat tog, hulle het elkeen 'n probleem, tog maar rustig ... redelik rustig ... rondbeweeg".

* Interne psigologiese omgewingsfaktore

Volgens tabel 3 was dit opmerklik dat al vyftien deelnemers verwys het na selfwaarde, kognitiewe aspekte en affektiewe aspekte, terwyl slegs tien deelnemers na die konatiewe aspekte verwys het

\section{Selfwaarde}

Die meeste deelnemers het by opname 'n lae sel fwaarde gehad.

"This is a beautiful place, the whole clinic ... and I felt, no, I can't live here. It's too nice for $m e^{n}$.

Dit blyk dat pasiënte gedurende behandeling hul selfvertroue herwin het en menswaardig en gerespekteer gevoel het. Dit is bereik deur lede van die interprofessionele gesondheidspan se persoonlike belangstelling, individuele aandag, respek, onvoorwaardelike aanvaarding, hoflikheid, erkenning en suksesvolle voltooiing van aktiwiteite by arbeidsterapie.

"Die feit dat jy tog skeppend en kreatief kan wees en nie ' $n$ niks of ' $n$ niemand is nie".

\section{Kognitiewe aspekte}

Met verwysing na tabel 3 is verskillende kognitiewe aspekte aangedui. Tien deelnemers het aangedui dat hulle tot insig gekom het.
"Alkoholprogram. Ek dink van al die programme het ek dit die mees leersaam- ste gevind. Dit het my laat besef ek het 'n probleem en dit het my tot insig ge- bring".
"Depressie is ' $n$ siekte soos enige ander siekte en hy kan jou net soos wat jy 'n maagseer het en hulle kan jou gesond maak vir die maagseer..."

Sewe deelnemers het deur hul persepsie van tyd aangetoon dat tyd 'n belangrike faktor in hul beleweniswêreld was. Vyf deelnemers het versoek dat arbeidsterapie vir langer tye oop sal wees. Een deelnemer was bewus daarvan dat 15 minute van die kapeldiens aan sang en 15 minute aan verkondiging van die Woord gespandeer is; hy wou meer tyd aan Woordverkondiging gespandeer hê. 'n Ander deelnemer het aangedui dat sy eerder met die psigiatriese verpleegkundige praat omdat sy tydens sessies met die psigiater voel sy moet haar sê sê, want daar is ander met groter probleme wat vir hom wag en sy voel sy mors sy tyd. Nog 'n deelnemer het daarop gewys dat die pastorale berader te besig is en nie tyd vir'n krisis het nie.

"En ek het soontoe gegaam, dis in vyftienminute sessies ingedeel ... Dis nie dr. $X$ se skuld dat hy nie verlede week hier kon wees nie, ... maar vanmóre het ek in vyfiig minute myself gekry".

"Hulle het altyd tyd. Dis een ding wat ek gesien het, maak nie saak wie aan diens was nie, hulle het altyd tyd vir jou gehad al was hulle hoe besig. Hulle sal hulle goed net daar neersit. Dan sal hulle vir jou tyd maak. En dis almal". 
Uit voorafgaande bevindings blyk dit dat gespesialiseerde terapietyd net $s o$ ' $n$ belangrike rol in psigiatriese behandeling speel as wat tegnologie in sjirurgiese behandeling speel. Verder is dit opmerklik dat 'n deurlopende vier-en-twintig-uur-beskikbaarheid van die psigiatriese verpleegkundige 'n noodsaaklike aanvulling en ondersteuning tot die intermitterende daaglikse terapiesessies deur ander terapeute bied.

\section{Affektiewe aspekte}

Tabel 3 dui op positiewe gevoelens soos gevoelens van welsyn, liefde, dankbaarheid en kalmte wat veral tydens ontslag en gedurende behandeling ervaar is. Dit was afgewissel deur negatiewe gevoelens van ontsteltenis, depressie en aggressie wat veral tydens opname en gedurende behandeling ervaar is. Voorafgaande kon op 'n verbetering in geesteswelsyn vanaf opname tot ontslag dui.

\section{Konatiewe aspekte}

Met verwysing na tabel 3 was dit ' $n$ algemene tendens by dié deelnemers dat hulle by opname moeg, verslae, sonder doel en sonder energie was, met 'n drang om hulself en soms selfs hul gesinne uit te wis.

Deur bemoediging en behandeling het hulle weer hul lus vir die lewe, energie, belangstelling, vooruitsigte, toekomsverwagtinge, motivering, dryfkrag en uitdagings teruggekry en besef dat selfmoord nie 'n oplossing is nie. Die lewe het weer sin en betekenis gekry en hulle kon die lewe weer aanpak.

\section{"My sin en belangstelling vir die toekoms was nog nooit so belangrik en uitdagend soos reeds nou deurdat ek ' $n$ nuwe insig en belangstelling daarvoor gekry en ont- dek het met my behandeling".}

\section{Eksterne sosiale omgewingsfaktore}

Uit tabel 4 blyk dit dat resultate uit deelnemers se belewenisse van eksterne sosiale omgewingsfaktore gelei het tot die subtemas van openbare menings, belewenis van medepasiënte, belewenis van verskillende lede van die interprofessionele gesondheidspan se bydraes en belewenis van die interaksiepatrone van lede van die interprofessionele gesondheidspan. Dit is verder duidelik dat deelnemers se belewenisse van laasgenoemde interaksiepatrone aan spesifieke lede van die interprofessionele gesondheidspan gekoppel was.

Dit het geblyk dat belewenisse van openbare menings gefokus het op die stigma wat aan geestesongesteldheid kleef.

"En hulle (tieners) het in die gang gesit en tekere gegaan dat my besoekers gesé het dit klink soos ' $n$ malhuis. En dis nie wat ek wil hê hulle moet dink ek in is nie".
Negatiewe belewenisse van medepasiènte het hoofsaaklik gesentreer om aanpassings by moeilike of tienerpasiënte, terwyl positiewe belewenisse van medepasiënte veral gehandel het oor groepterapie, die gevoel van universaliteit en sosialisering. Vier deelnemers het spesifiek aangedui dat persoonlike deelname en bespreking van hul probleme in groepe mecr waarde het as didaktiese groepe. Alhoewel dit nie deel van die navorsingsdata was nie, word 'n gedeelte uit 'n gedig wat die kwaliteit van 'n anonieme pasiënt se belewenis van 'n medepasiënt, illustreer met eersgenœmde se toestemming, aangehaal:

"Ag Heer, sal ek ook word soos hierdie vrou?" (Stols, 1992: 179).

Met betrekking tot die belewenisse van verskillende lede van die interprofessionele gesondheidspan se bydraes tot herstel, was dit opmerklik dat daar verskillende menings daaroor was. Elkeen van die psigiater, sielkundige, psigiatriese verpleegkundige, arbeidsterapeut en pastorale berader se bydraes is afsonderlik deur verskillende deelnemers as die belangrikste bydrae tot hulle herstel aangedui.

In die lig van voorafgaande het een deelnemer spesifiek genoem dat die psigiater op grond van sy opleiding en ervaring die belangrikste invloed op sy behandeling gehad het. 'n Ander deelnemer het ook die psigiater as die belangrikste faktor genoem, maar daarmee saam gesê dat dit eintlik onregverdig is om die verpleegkundige wat die alkoholgroepe gehou het, se rol in sy behandeling ondergeskik te stel aan dié van die psigiater. Die moontlikheid bestaan dat voorafgaande aan die openbare mening gekoppel kan word.

Dit is opmerklik uit tabel 4 dat die fokus van deelnemers se belewenis van hul interaksie met lede van die interprofessionele gesondheidspan, kwantitatief en kwalitatief, hoofsaaklik om hul interaksies met verpleegkundiges gesentreer het. Die klem het hoofsaaklik daarop geval dat verpleegkundiges gebruik gemaak het van die terapeutiese self deur die aspekte van omgee, ondersteuning, liefdevolheid, begrip, beskikbaarheid, oopheid, luister, konsekwentheid, uitreiking en totale aanvaarding (deur die skep van 'n informele klimaat) toe te pas. Die kern hiervan kan moontlik gekoppel word aan die deurlopende vier-en-twintig-uur-'n-dag-beskikbaarheid van die verpleegkundige teenoor intermitterende terapiesessies van ander lede van die interprofessionele gesondheidspan. Dit reguerdig dus opname en behandeling van psigiatriese pasiënte in 'n terapeutiese milieu waar psigiatriese verpleegkundiges hierdie rol kan vervul.

Uit tabel 4 kom dit verder voor asof interaksiepatrone van lede van die interprofessionele gesondheidspan hoofsaaklik bestaan het uit dié wat gerig was op die instandhouding van positiewe interpersoonlike verhoudings en dié wat gefokus het op probleemgerigte of werkgerigte tussentrede. Deelnemers het meer klem gelê op belewenisse van interpersoonlike verhoudingsaspekte en wel soos dit veral deur die verpleegkundiges gefasiliteer was. Tot ' $n$ mindere mate is daar klem gelê op werksgerigte tussentredes wat min of meer ewe veel deur psigiaters en verpleegkundiges gefasiliteer was Ondersteuning en doelgerigte aktiewe hulpverlening is ewe veel deur arbeidsterapeute gefasiliteer

"I was informed sister A was looking for me. She was warm and loving and explained in detail about everything".

"...en jy't weer eens besef dat jy as wildvreemdeling $l \hat{e}$, en hier is iemand wat werklik vir jou omgee, ..."

"...I just cried and all she did was put her arm around me and hold me and that meant so much to me, you know, and she said:

'Cry it out', and it felt wonderful ...".

"... en hulle was enige tyd van die nag 'available' om mee te gesels".

"... simpatieke benadering word op so 'n wyse gedoen dat pasiënt (ek) die gevoel gekry het dat ek nie absoluut afhanklik is nien.

Die aspek van raadgee het gedui op leiding gee, anbevelings maak, alternatiewe en moontlike oplossings bied, terwyl strengheid gedui het op dissipline, konfrontasie, georganiseerdheid en gestruktureerdheid.

"... en dokter sal sê, ek verstaan hoe jy voel, jy weet. Jy wil uiting gee aan jou gevoelens, maar miskien is dit nie die beste manier om dit te doen nie."

\section{- Belewenis van geestelike omgewing (Godsbelewenis)}

Met verwysing na tabel 5 is dit nodig om daarop te let dat godsbelewenis intern, sowel as ekstern kan bestaan. Skynbaar is godsdiens 'n "taboe"-onderwerp wat deur sekere deelnemers omseil is.

"Ek moes hierdie ou hierso langs die kapel sien, ... toe sê ek vir hom ek wil hom nie sien nie want ek het my eie kerk en ek gaan daarvolgens ... ek wil geen ander godsdiens in my lewe, ek het dit nie nodig nie ..."

Ten spyte daarvan dat dit uit die onderhoude geblyk het dat sommige deelnemers dit as 'n "taboe"-onderwerp ontwyk het, is 'n intense behoefte aan ' $n$ uitbreiding van die pastorale beradingsdienste op 'n kwalitatiewe wyse weergegee.

"... waar ek so verskriklik beangstig was, het ek gevoel ek het iemand nodig om net vir my ' $n$ gebed te doen, jy weet ... en hy was nie beskikbaar nie. Hy het ander 


\section{TABEL 5}

TEMA: BEHANDELINGSBELEWENIS VAN GEESTELIKE OMGEWING

\begin{tabular}{|l|l|}
\hline$N=7$ & $\begin{array}{l}\text { Verwye na geestellke voeding } \\
N=2-\text { Voorsien in geestelike behoefles (psigiater) } \\
\end{array}$ \\
& $N=2-$ Gebrek aan beskikbaarheid van pastorale beraders \\
& $N=2-$ Medepasiënte doen voorbidding \\
& $N=1-$ Dui op intense behoefte aan voile oorgawe aan God \\
\hline
\end{tabular}

pasiënte gehad. ... en toe ek nou uiteindelik by hom kom toe is dit nie meer so van belang nie ..."

"Ek het daar geklop, seker drie keer, maar niemand het die deur oopgemaak nie..."

"Die mense wat in daardie kerk sit soek iets in die Bybel om aan vas te klou, om hom te help om sy probleem op te los. Ek soek dit. Ek het gaan kyk na Job ..."

\section{- Belewenis van ' $n$ integrasie van verskillende kategorieë}

Samestellings van verskillende kategoriec is deurgaans opgemerk. 'n Beduidende aantal deelnemers het 'n integrasie van veral die psigologiese interne omgewingsfaktore met die eksterne sosiale omgewingsfakıore weergegee. Dit blyk dat lede van die interprofessionele Sesondheidspan as fasiliteerders in die mobilisering van omgewingsfaktore optree. Dit kom verder voor asof die verskillende groepe uit die interprofessionele gesondheidspan volgens prioriteitsvolgorde meestal die hoogste insidensie vir fasilitering van affektiewe faktore toon. Daarna volg fasilitering van kognitiewe faktore. Psigiaters toon die hoogste insidensie vir fasilitering van kognitiewe faktore. Die verpleegkundiges se fasilitering van selfwaarde vind meer dikwels plaas as fasilitering van die konatiewe faktore en die pastorale beraders se fasilitering van godsbelewenis vind weer meer dikwels as dié van die konatiewe faktore plaas (Stols, 1992: 55-56).

\section{- Belewenis van nie-spesifieke omgewingsfaktore}

Die mees beduidende nie-spesifieke faktore wat deur deelnemers angedui was, is vriendelikheid, hulpvaardigheid en professionaliteit. Nie-spesifieke omgewingsfaktore wat deur deelnemers beleef was, was as vertrekpunt gebruik om verdere verkenning in die transkripsies te doen. Nadat verkenning gedoen is, is die nie-spesifieke faktore geherklassifiseer sodat daar geen nuwe karegorie oorgebly het nie.

\section{Kontekstuele beskrywing}

Pasiënte se belewenis van hul behandeling deur die interprofessionele gesondheidspan, is deur middel van ' $n$ inhoudsanalise geanaliseer. Die uniekheid van die konteks van verskillende

\section{LITERATUURKONTROLE}

Die navorsingsresultate en literatuurkontrole ondersteun mekaar wedersyds ten opsigte van veral die volgende aspekte:

Die metateoretiese aanname dat die mens ' $n$ unieke, komplekse, geintegreerde biopsigososiale en geestelike wese in totaliteit is, is bevestig. Die klem val veral daarop dal die mens ' $n$ geĩntegreerde geheel is wat nie op gefragmenteerde wyse benader kan word nie. Daar is bepaalde interaksiepatrone tussen die komponente van die mens in totaliteit. Pasient belewenis is ook uniek en dit word bepaal deur faktore soos inligtingprosessering, verwysingsraamwerk, aard van geestesongesteldheid en kommunikasiegesteldheid van die individu (Bellante, 1973: 3277-B, Oral Roberts University, 1990: 228-229, Poggenpoel, 1988: 5, Poggenpoel, 1990: 18).

Die noodsaaklikheid vir die bestaan van 'n komplekse en samewerkende of geintegreerde interprofessionele gesondheidspan, wat aan die kompleksiteit en geintegreerde totaliteit van pasiènte se behoeftes kan voldoen, is vasgestel. Ter aansluiting by die kompleksiteit van die gesitueerdheid van die individu is daar op die kompleksiteit van die funksies en afsonderlike modelle van die verskillende lede van die interprofessionele gesondheidspan gewys (Bachur \& Rabins, 1984: 76, Mcllugh \& Knowles, 1984: 36, Stols, 1992: 78 en 81).

In hul interaksie met pasiènte het lede van die interprofessionele gesondheidspan hoofsaaklik 'n fasiliterende rol vervul waarin hulle gerig was op die mobilisering van interne en eksterne omgewingsbronne van pasiènte.

Daar was bepaalde interaksiepatrone tussen lede van die interprofessionele gesondheidspan en pasiènte.

'n Positiewe interpersoonlike verhouding deur die mobilisering van veral affektiewe omgewingsbronne, was die basis vir probleemgerigte terapeutiese tussentrede. In laasgenoemde word veral kognitiewe omgewingsbronne gefasiliteer. Die psigiatriese verpleegkundige as fasiliteerder van ondersteuning, deur gebruikmaking van die terapeutiese self, word meerendeels deur deelnemers se weergawes van hul belewenisse beklemtoon (Elliot, 1979: 285, Kurtz \& Gramman, 1972: 114, Poggenpoel, 1990: 10 12).

Betroubaarheid van navorsingsdata is deurentyd deur sowel die sketse as onderhoude bevestig. Slegs in die geval van een deelnemer wat aangedui het dat hy nie van handwerk hou nie, het dit uit verdere verkenning geblyk dat dit 'n verdedigingsmeganisme was om te ontken dat die finansiële koste daaraan verbonde hom van deelname aan arbcidsterapie weerhou het. Oor die algemeen was deelnemers tydens die onderhoude gemaklik, oop en spontaan sonder om die indruk te skep dat die inligting wat hulle verskaf het hulle ongemaklik laat voel het.
Die terapeutiese milieu is ' $n$ betekenisvolle komponent in die behandeling van psigiatriese pasiënte (Beck, Rawlins \& Williams, 1988: 460, Peens, 1990: 7)

Die enigste teenstrydigheid tussen die navorsingsresultate en literatuurkontrole wat voorgekom hel was die feit dat interprofessionele konflik as 'n algemene verskynsel uit die literatuur voorgekom het, 
terwyl dit skynbaar nie die geval in hierdie kontekstuele studie was nie.

Verder het deelnemers lede van die interprofessionele gesondheidspan hoofsaaklik as afsonderlike individue beleef, al hoewel daar 'n gemeenskaplike filosofie van vriendelikheid, hulpvaardigheid en professionaliteit, asook ooreenstemmende benadering- en interaksiewyses geïmpliseer was. Uit die literatuur is daar 'n aanpassing van die probleemgeoriënteerde plan vir elke pasiënt aanbeveel, waar 'n bepaalde lid van die interprofessionele gesondheidspan vir elke afsonderlike aksie verantwoordelik gehou word. Dit behoort tydens 'n spanvergadering gekoördineer te word (Stols, 1992: 96-97; Williams, 1988: 80).

\section{GEVOLGTREKKINGS}

In hul interaksie met pasiënte het lede van die interprofessionele gesondheidspan 'n fasiliterende rol vervul waarin hulle gerig was op die mobilisering van interne en eksterne omgewingsfaktore van pasiënte.

Die klem het grotendeels geval op deel nemers sc belewenis van hul behoefte aan liefde en emosionele ondersteuning en die wyse waarop verpleegkundiges aan dié behoefte voldoen, deur vier-en-twintig-uur-per-dag-teenwoordigheid en gebruikmaking van interaksiewyses soos omgee, simpatie, gerusstelling, oopwees, betoning van liefde, begrip, beskikbaarheid, luister, strengheid, aanmoediging van onafhanklikheid en uitreiking.

Daarnaas het verpleegkundiges en psigiaters ewe veel die mobilisering van pasiènte se kognitiewe prosesse as 'n wyse van terapeutiese tussentrede gefasiliteer. Kognitiewe behandeling het gekonsentreer op deelnemers se verkryging van insig en 'n bewussyn van tyd as waardebepalend. Dit blyk dat 'n positiewe interpersoonlike verhouding deur die mobilisering van affektiewe bronne ' voorwaarde vir probleemgerigte terapeutiese tussentrede en vir toepassing van die verpleegproses in psigiatriese behandeling kan wees. Verder blyk dit dat daar 'n leemte in die mobilisering van pasiënte se konatiewe omgewingsfaktore was, terwyl verbetering in selfwaarde positief beïnvloed is.

Die mens is bevestig as ' $n$ unieke, komplekse, geïntegreerde biopsigososiale en geestelike wese in totaliteit.

Om aan die komplekse, geïntegreerde aard van die mens se gesondheidsbehoeftes te kan voldoen, is die bestaan van 'n komplekse, geïntegreerde interprofessionele gesondheidspan geregverdig.

In dié spesifieke konteks van studie is 'n behoefte aan verbeterde samewerking en integrasie van die funksies van die lede van die interprofessionele gesondheidspan egter geidentifiseer, alhoewel deelnemers geen konflik tussen lede van die interprofessioncle gesondheidspan gereflekteer het nie. Verder kon die afwesighcid van 'n maatskaplike werker 'n verbandhoudende faktor in die beduidende afwesigheid van declnemers se belewenis van gesins- en gemeenskapsbetrokkenheid gewees het. Uitbreiding van die pastorale funksies is aangedui. Die beleweniswêreld van pasiënte rakende die stigma rondom geestesongesteldheid, hul belewenis van 'n oorgang van negatiewe na positiewe emosies namate hulle vir ontslag gereed geword het en die betekenis wat hulle geheg het aan begrippe soos vriendelikheid, hulpvaardigheid en professionaliteit is verken. Dit blyk dat die terapeutiese milieu 'n betekenisvolle komponent in die behandeling van psigiatriese pasiënte is wat deur die vier-en-twintig-uurdeurlopende teenwoordigheid van die verpleegkundige en deur die spesifieke emosionele klimaat wat geskep word, in stand gehou word.

Voorafgaande gevolgtrekkings met betrekking tot die interaksie tussen die pasient, interprofessionele gesondheidspan en terapcutiese milieu in 'n binnehospitaalopset word in figuur 1 geilllustreer soos dit deur die bevindinge van hierdie studie gereflekteer word. Dit stel dus nie die ideaal daar nie (Stols, 1992: 100-102).

Figuur 1 dui op die interaksie tussen psigiatriese verpleegkundiges en psigiaters en die afwesigheid daarvan cussen ander spanlede soos dit deur deelnemers weergegee is. Daarvolgens is daar ook ' $n$ afwesigheid van interaksie tussen pasiënte en maatskaplike werkers en tussen pasiente en die gemeenskap. In terme van emosionele nabyheid is die psigiatriese verpleegkundige die naaste aan die pasiënt, daarna die psigiater en daarna die ander spanlede. Deur haar vier-en-twintig-uur'n-dag-beskikbaarheid voorsien die psigiatriese verpleegkundige in die instandhouding van 'n gestruktureerde terapeutiese milieu, waar sy 'n bepaalde emosionele klimaat fasiliteer en die funksies van die verskillende lede van die interprofessionele gesondheidspan koördineer (Stols, 1992: 98-102).

\section{TEKORTKOMINGE}

Tekortkominge van hierdie studie wat na vore gekom het, was die volgende:

Data-insameling van al die deelnemers kon nie gelykıydig plaasvind nie. Dit kon die belewenis van deelnemers gekontamineer het. Die navorser het egter die tyd van data-insameling nie vooraf bekend gemaak nie en het die tydperk van data-insameling so kort as moontlik gehou.

Deelnemers is toegelaat om die spontane sketse in ongekontroleerde omstandighede te skryf. Hulle kon tydens die neerskryf daarvan deur andere beinvloed word. Hierdie leemte is gedeeltelik deur die bevestiging van inligting tydens die opvol gonderhoude uitgeskakel.
Die navorser het tydens hierdie onderhoude leidende vrae met betrekking tot lede van die interprofessionele gesondheidspan wat nie in die spontane sketse genoem was nie, gestel. Dit is agterna gekorrigeer omdat slegs dié gedeeltes van transkripsies gebruik is wat uit die spontane sketse voortgespruit het en wat op 'n nie-direktiewe wyse verkry is.

Die loepassingswaarde van hierdie studie is beperk tot die homogene kulturele milieu en tot die konteks waarin dit onderneem is.

Die kwaliteit en geldigheid van data uit die spontane sketser en opvolgonderhoude was afhanklik van die deelnemers se geskrewe en mondelinge vaardighede. Tekortkominge in die vermoe van een kon gedeeltelik deur vaardighede in die ander aangevul word.

Die navorser se subjektiewe effek op die prosesse van onderhoudvoering en dataverwerking was gekontroleer deur die gebruikmaking van spontane sketse en 'n medekodeerder. Waar die navorser self 'n psigiatriese verpleegkundige is, kon dit deelnemers beinvloed het om meer op hul belewenis van die psigiatriese verpleegkundige te fokus.

Die wyse waarop die tema aan declnemers gestel was om by hul begrip van die interprofessionele gesondheidspan aan te pas naamlik "My ervaring van my behandeling deur die personeel uit die verskillende beroepsgroepe" kon leidend gewees het. Dit kon moontlik as sodanig geïnterpreteer gewees het dat dit die afwesigheid van onderlinge kohesie tussen spanlede geïmpliseer het, alhoewel dit onwaarskynlik was.

Die indeling van selfwaarde as 'n subkategorie van inteme psigologiese omgewingsfaktore kon moontlik as onderafdeling van die kognitiewe kategorie geplaas gewees het.

\section{TOEPASSINGSWAARDE}

Die toepassingswaarde van dié studie geld vir:

\section{- Nasionale beleidformulering}

Voordat daadwerklike stappe geneem word om psigiatriese afdelings in algemene hospitale te vestig, word dit aanbeveel dat die invloed van die terapeutiese milieu op die behandeling van psigiatriese pasiënte en die praktiese toepaslikheid daarvan in 'n algemene hospitaalopset eers noukeurig ondersoek en nagevors word.

\section{- Verpleegnavorsing}

Enkele aspekte wat onder andere prominent as moontlike navorsing onderwerpe na vore gekom het, was die volgende:

Die psigiatriese verpleegkundige se bydrae in die koördinering van die lede van die interprofessionele gesondheidspan se funksies 


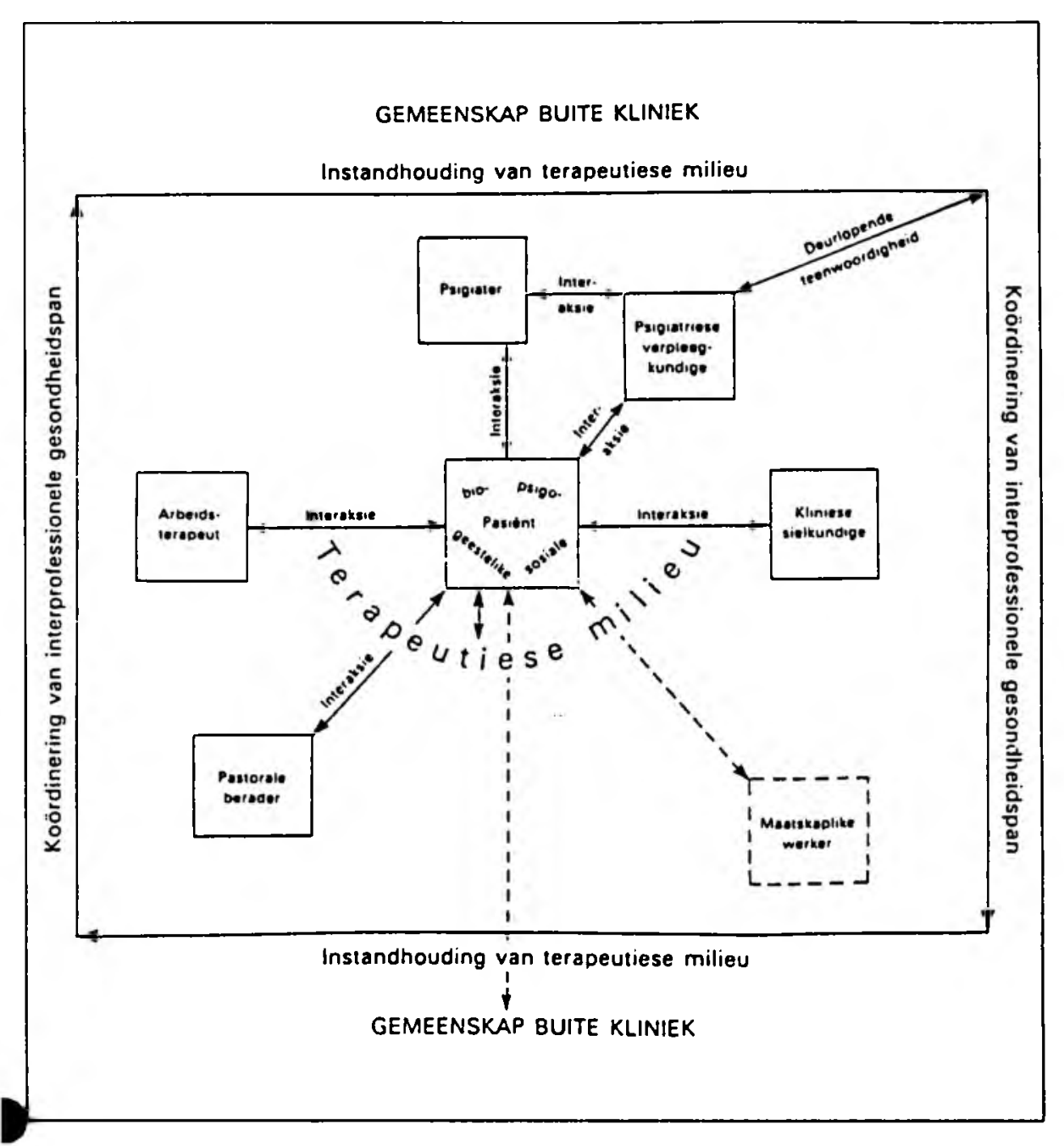

\section{Flguur 1 \\ Interaksles tussen die Psiglatriese Paslënt, dle Interprofesslonele Gesondheldspan en dle Terapeutiese Milieu}

en die instandhouding van die terapeutiese milieu.

Verkenning van die wyses waarop die psigiatriese verpleegkundige die konatiewe interne psigologiese omgewingsbronne van psigiatriese pasiënte kan mobiliseer.

Verkenning van interaksiepatrone wat psigiatriese verpleegkundige kan aanwend om interne en eksterne omgewingsfaktore van pasiente te mobiliseer en wat die daarstelling van 'n positiewe interpersoonlike verhouding sal bevorder.

Die kultuurgebonde aard van psigiatriese pasiente se persepsie van tyd en van selfwaarde of seltbeeld.

\section{- Verpleegonderwys}

Resultate uit hierdie studie kan 'n waardevolle toevoeging wees tot die teoretiese kennisbasis wat in die verskillende kurrikul ums vir kursusse in psigiatriese verpleegkunde ingesluit word. Bevestiging van metateoretiese aannames uit hierdie studie kan as vertrekpunt vir onderrig van studente in psigiatriese verpleegkunde, voorgehou word. en in besonder deur die psigiatriese verpleegkundige aanvaar te word. So sal die rol van die psigiatriese verpleegkundige in die behandeling van elke pasiënt gedefinieer word.

In die behandeling van psigiatriese pasiënte is dit belangrik dat psigiatriese verpleegkundiges sensitief en empaties sal wees vir die negatiewe emosies wat met byvoorbeeld konfrontasie, gedragsterapie of ander terapeutiese lussentredes gepaard mag gaan, asook positiewe gevoelens soos genot waaraan vordering gemonitor kan word.

Psigiatriese verpleegkundiges behoort in hul interaksie met psigiatriese pasięnte steeds gerig te bly op interaksieprosesse wat positiewe interpersoonlike verhoudings fasiliteer.

Psigiatriese verpleegkundiges behoort tydens groepterapie meer klem te lê op persoonlike deelname en bespreking van elkeen se eie probleme eerder as didaktiese groepe.

Pasiente se gesinne behoort by behandeling betrek te word en gesinsterapie as sodanig kan effektief in die kliniek onderneem word.

Met die klem op die interprofessionele gesondheidspan

'n Ondersoek behoort geloots te word na die verskynsel van pasiênte se aversie vir deel name aan handvaardige aktiwiteite en van die finansielle vergoedingsisteem vir arbeidsterapie.

Psigiaters sal ernstig moet besin oor die wyse waarop hulle pasiente tydens hul eie verlof of afwesigheid sal hanteer om die negatiewe effek daarvan uit te skakel

Daar is ' $n$ groot behoefte aan uitbreiding van die pastorale beradingskomponent met insluiting van tyd vir informele betrokkenheid by pasiente.

Vaardighede om die ondersteunende funksie deur die terapeutiese gebruikmaking van die self te vervul, behoort beklemtoon te word.

Die fasilitering van 'n positiewe interpersoonlike verhouding as basis van alle werksgerigte, probleemgerigte verpleegkundiges in die praktyk behoort toegepas te word.

\section{SPESIFIEKE AANBEVELINGS}

Vir die betrokke kliniek waar die studie ondemeem is, is spesifieke riglyne aanbeveel om die verergering van geestesongesteldheid te voorkom:

\section{Met die klem op die psigiatriese verpleegkundige}

Onderlinge spansamewerking en groepskohesie kan bevorder word o.a. deur die instel van 'n enkcle beramingsvraelys wat by opname deur die pasięnt voltooi kan word. Verantwoordelikheid vir bereiking van bepaalde doelwitte van die behandelingsprogram behoort deur spesifieke lede van die interprofessionele gesondheidspan 'n Bekendstellingsprogram deur die media is nodig om die stigma wat aan geestesongesteldheid gekoppel word, die nek in te slaan.

Afsonderlike behandelingseenheid vir adolessente, weg van die volwassenes af behoort geskep te word.

(Stols, 1992: 107-112)

\section{SAMEVATTING}

Uit voorafgaande studie is die kwantiteit en kwaliteit van verskillende belangrike aspekte van psigiatriese pasiênte se belewenis van hul behandeling deur die interprofessionele gesondheidspan verken en ontdek. behandeling deur die interprofessionele gesondheidspan het primerr geval op hul behoefte aan veral emosionele ondersteuning en die wyse waarop verpleegkundiges meestal daaraan voldoen het. "Baie dankie vir al u
Die fokus van deelnemers se belewenis van hul 
liefde. Dit het baie van ons nodig en $u$ het dit uitgedeel".

Waar dit uit die literatuur blyk dat daar 'n lae korrelasie tussen pasiëntbelewenis en personeelbelewenis is, is dit belangrik dat daar al hoe meer gelet sal word op die pasient se bel eweniswêreld (Schaffer \& Dreyer, 1982: 127 en Luft, Smith \& Krace, 1978: 505).

\section{BRONNELYS}

ABDELLAH, F.G. AND LEVINE, E. 1979 Better patient care through nursing research. New York. London: MacMillan.

BACHUR, J.A. AND RABINS, P.V. 1984: Multidisciplinary teams. The positive aspects. Clinical Gerontologist 2(3), Spring 1984: 69-71.

BECK, C.M., RAWLINS, R.P. AND WILLIAMS, S.R. 1988: Mental health psychiatric nursing. A bolistic life cycle approach. St Louis. Washington DC. Toronto: CV Mosby Co.

BELLANTE, A.J. 1973: Working towards developing a residential treatment model: A residential treatment community reflects upon itself. Dissertation Abstracts Intemational 33 (7B), January 1973: 3277.

BURNS, N. AND GROVE, S.K. 1987: The practice of nursing research, conduct, critique and utilization. Philadel phia: Saunders.

COBB, A.K. AND HAGEMASTER, J.N 1987: Ten criteria for evaluating qualitative research proposals. Journal of Nursing Education 26 (4), April 1987: 138-143.

ELLIOT, R. 1979: How clients perceive helper behaviours. Journal of Counseling Psychology 26(4), 1979: 285-294.

KERLINGER, F.N. 1986: Foundation of behavioural research. New York: Holt, Rinehart and Winston, Inc.

KURTZ, R.R. AND GRUMMON, D.L. 1972: Different approaches to the measurement of therapist empathy and their relationship to therapy outcomes. Journal of Consulting and Psychology 39 (1), 1972: 106-115.

LUFT, L.L., SMITH, K. AND KRACE, M. 1978: Therapists, patients and inpatient staff's views of treatment modes and outcomes. Hospital and Community Psychiatry 29 (8),August 1978: 505-511.

MACDONALD, K. AND RITZER, G. 1988: The sociology of the professions. Work and Oocupations. An International Sociological Journal 15(3), August 1988:251-271.

MCHUGH, S. AND KNOWLES, B. 1984: A multidisciplinary approach in psychotherapy. British Journal of Occupational Therapy 47(2), February 1984: 36-38

MOUTON, J. EN MARAIS, H.C. 1988: Basic concepts in the methodology of the social sciences. Pretoria: RGN.

ORAL ROBERTS UNIVERSITY 1990-1992: Catalog, School of Arts and Sciences, Business, Education, Nursing and Theology and Missions, Volume 17, Number 1. Tulsa, Oklahoma: Oral Roberts University.

OMERY, A. 1983: Phenomenology: A method for nursing research. Advances in Nursing Science 5(2), January 1983:49-63.

PARSE, R.R., COYNE, A.B. AND SMITH, MJ. 1985: Nursing Research. Qualitative methods. Maryland: Brady Communications Company.

PEENS, T. 1990: Selfuerwesenliking by die psigiatriese verpleegkundige vanuit 'n Christussentriese benadering. Johannesburg: RAU.

POGGENPOEL, M. 1984: Die funksies van die psigiatriese verpleegkundige in Suid-Afrika. Kaspstad. Wetten. Johannesburg: Juta.

POGGENPOEL, M. 1989: Psychiatric nursing conceptual model. (Final research report). Johannesburg: RAU.
POGGENPOEL, M. 1990: Psychiatric nursing model. An interaction approach focused on facilitating a patient's quest for wholeness. Perspectives in psychiatric nursing care. (Ongepubliseerde artikel). Johannesburg: RAU.

SCHAFFER, J.B. AND DREYER, S.F. 1982 Staff and inpatient perceptions of change mechanisms in group psychotherapy. American Journal of Psychiatry 139 (1), January 1982:127-128.

SEIDEL, S. 1986: Part of the team. Nursing Times 82 (27), 9 July 1986: 64

STOLS, H.E. 1992: Die behandelingsbelewenis van psigiatriese pasiènte in 'n privaat kliniek. (Ongepubliseerde verhandeling). Johannesburg: RAU.

SUID-AFRIKA (REPUBLIEK). SAVV. 1988: Voorgestelde beleidsdokument - Die psigiatriese verpleegkundige: psigoterapie. Pretoria: SARV.

WILLIAMS, B.E. 1988: Parents and patients: Members of an interdisciplinary team on an adolescent inpatient unit. Clinical Social Work Journal 16(1), Spring 1988: 78-91.

WILSON, H.S. 1985: Research in Nursing California: Addison Westley Publishing Company Inc.

WILSON, H.S. AND KNIESL, C.R. 1983 Psychiatric Nursing. Massachusetts Addison-Wesley $\mathrm{Co}$.

WOODS, N.F. AND CATANZARO, M. 1988 Nursing research theory and practice. St Louis: The CV Mosby Co.

H.E. Stols B. Cur., B.A.Cur.
Verbonde aan T.P.A. Primére Gesondheids-
dienste
Minrie Greeff D. Cur.
Doktor: Departement van Verpleegkunde-
RAU
M. Poggenpoel D. Phil.
Professor: Verpleegkunde RAU

